\title{
Food Risk Perception and Its Impact on the Consumers' Purchasing Behavior
}

\author{
Jiaping Tong \\ School of Economics, Shanghai University, Shanghai 201900, China \\ tjpwelcome@163.com
}

\begin{abstract}
Keywords: Food risk perception; Certificate of quality; Choice experiment; Cognitive bias; Purchasing behavior
\end{abstract}

\begin{abstract}
Basing on the milk, the main idea of this article is to analyze the food risk perception and its impact on the consumers' purchasing in certificates of food quality based on the empirical evidences of consumers in Hangzhou. The empirical study reveals the four factors- social risk consciousness, acquaintance with the certificates of food quality, individuality, trust-effecting the food risk perception, and the characteristic of overestimating the objective risks of food which have an important impact on the purchasing. Because of asymmetric information and subjective risk perceptions, instead of preference to the brands, consumers tend to purchase milk with more certificates of food quality by consumption habits, trusts in certification authority and the acquaintance with the certificates of food quality. When there is a wild price gap, it may change the purchasing behaviors.
\end{abstract}

\section{Introduction}

The recent spate of food safety incidents has greatly increased consumers ' awareness of food safety risks, which also caused the dairy industry and other industries received great trauma. Because of the information asymmetry in the food industry, consumers ' awareness of self-protection improves the cognition of food risk and then changes the purchase behavior. Therefore, we discuss how food risk cognition affects consumers ' purchasing behavior, and put forward some suggestions on the rational consumption of consumers, the improvement measures between enterprises and the government.

Risk cognition refers to the possibility that a consumer can perceive the performance of a purchased product without expectation when buying a decision ${ }^{[1]}$. Once consumers perceive the purchase risk, their consumption behavior will change accordingly ${ }^{[2]}$. However, consumers ' perception of risk needs to be analyzed in the social and cultural context in which they are embedded $^{[3]}$.

According to risk theory, risk has an acceptable range, and once the consumer's perception of risk exceeds that, consumers take steps to reduce the level of risk to an acceptable level, and the higher the risk perception, the more likely consumers will take action to mitigate the risk ${ }^{[4]}$.

Huang points out that consumers will also reduce their food safety risks by changing their food-buying decisions. There is a negative correlation between the level of risk cognition and consumers ' willingness to purchase food ${ }^{[5]}$. Because the severity of adverse consequences of food hazards is far greater than the general product performance to achieve the expected purchase target risk, consumer food safety evasion is particularly important ${ }^{[6]}$. Bai Junfei (2003) believes that the higher the consumer's own health evaluation, the higher the willingness to pay ${ }^{[7]}$. Zhou Jiehong (2004) by studying the consumer's attitude to vegetable safety and buying behavior in Zhejiang Province, the paper emphasizes that consumers ' concern about vegetable safety significantly affects the willingness to pay ${ }^{[8]}$. Similarly, the degree of anxiety about food safety (Wu Linhai, 2010) also has a positive effect on consumers ' willingness to pay ${ }^{[9]}$. Certification of traceable food can significantly improve consumers ' expectations and willingness to pay for the safety of the food they buy, and consumers are more reliant on products certified by government agencies ${ }^{[10]}$. Without involving consumers ' subjective risk perceptions, consumers are willing to pay higher prices for 
traceable milk that is certified by Government.

Although the research on the cognition and Behavior of consumer food safety is more dispersed, and the basic limitation is the Food Safety risk cognition, the safe food payment willingness and so on investigation analysis, has not more analyzed the influence consumer objective factor and the consumer subjective cognition existence relations, The function mechanism of risk cognition to consumer purchase behavior is far from forming systematic research results. Therefore, this article tries to expand the related conclusion of food risk cognition and purchase behavior. On the basis of analyzing the influence factors of food risk cognition, this paper analyzes the relationship between food risk cognition and the choice of two kinds of goods with no quality certification and different quality certification. Recent studies have not taken into account the subjective risk perceptions of consumers, who assume that subjective risk perceptions are average or do not have exaggerated risk perceptions, and that the relationship between different types of authentication and purchase behavior is analyzed. However, this is inconsistent with the risk perception of high reality, which is not objective. Therefore, in the study, we considered the common high subjective risk cognition factors in the food field, so that the research is more realistic.

\section{An Empirical Analysis of Food Risk Cognition on Consumers' Purchasing Behavior}

Subjective Food Risk Cognition and Purchase Behavior of Certified Commodity. Based on the relevant research literature, the Pearson Card test, the correlation test among variables, and the collinearity test are constructed to construct a two classified nonlinear econometric analysis model to determine the relationship between consumer subjective risk cognition and the purchase of certified milk. In the research model, consumers take the certified milk purchase behavior as the explanatory variables, social risk consciousness, trust level, consumer level and understanding level as explanatory variables. After the corresponding expansion of the measurement of explanatory variables, the $\mathrm{X}_{2}=$ "education level", respectively, the higher the value, the greater the level of education; $X_{1}=$ "Consumption habit", the greater the value of the more the difference in the purchase habit; $\mathrm{X}_{4}=$ "The understanding of food quality certification", the greater the value of food quality certification of the more understanding; $X_{5}=$ " The trust of international certification bodies ", the greater the value of the more representatives trust the international institutions; $X_{3}="$ The risk consciousness to others ", the greater the value represents the less social risk consciousness. Logarithmic likelihood value (Ln lik) for probit model fitting. Are higher, indicating the Probit model fitting degree $(\mathrm{p}<0.01)$ is high (see table 1$)$.

Table 1 Coefficient and its significance of related factors that have important influence on consumers' purchasing behavior

\begin{tabular}{cccc}
\hline & Model1 & Model2 & Model3 \\
\hline Education $\left(X_{2}\right)$ & $0.033^{* *}$ & $0.021^{* * *}$ & $0.015^{* *}$ \\
Consumption habits $\left(X_{1}\right)$ & $1.236^{*}$ & $1.05^{*}$ & $0.647^{*}$ \\
Understanding of food Quality & $-0.028^{* * *}$ & $-0.02^{* *}$ & $-0.013^{* * *}$ \\
$\quad$ certification $\left(X_{4}\right)$ & & & \\
Degree of trust in international & $-0.79^{*}$ & $-0.35^{* *}$ & $-0.359^{*}$ \\
certification bodies $\left(X_{5}\right)$ & & & \\
Social risk Awareness $\left(X_{3}\right)$ & $1.75^{* *}$ & $0.93 *$ & $0.801 *$ \\
DW & & 1.32 & \\
Adjusted $\mathrm{R}^{2}$ & & 0.99 & \\
\hline
\end{tabular}

(NOTE: $* * *, * * *$, respectively, $1 \%, 5 \%, 10 \%$ the significance of the level. In addition, the model one for the selection of the purchase of milk without food quality certification; Model two is relative to HACCP and ISO9001 choose to purchase organic food certification logo of milk; model

three is relative to organic food and ISO9001 choose to buy HACCP certified milk. )

Through the comparison, we can conclude that the social risk awareness and the former 
coefficient of personal consumption are positive, the smaller the value of the independent variables, the higher the social risk consciousness and the better the personal consumption habit, and the more milk that the quality certification mark in the package is purchased. Similarly, the less understanding of food quality certification and the more trust in the international certification body of consumers, but also tend to buy food quality certification of more milk. Although one kind of situation is organic food vs HACCP and ISO9001, another situation is HACCP vs organic food and ISO9001, but the consumer in the brand does not have the difference situation, the preference buys the food quality attestation much milk.

The social risk consciousness has positive correlation effect on the dependent variables (risk cognition), the higher the awareness of social risk, the more likely to buy more food certified milk; the more knowledge about food quality certification, the more the tendency of the food quality certification to mark the milk is not so large; social risk awareness affects consumer risk perception and thus influences purchase behavior more significantly.

\section{The effect of price on buying behavior.}

Table 2 Organic food and HACCP certification, SO9001 certification, consumer choice under different prices

\begin{tabular}{cccccc}
\hline \multicolumn{2}{c}{$\begin{array}{c}\text { Item } \\
\text { Same condition }\end{array}$} & \multicolumn{2}{c}{ A } & \multicolumn{2}{c}{ B } \\
\multicolumn{1}{c}{$\begin{array}{c}\text { Sondit- } \\
\text { ion }\end{array}$} & Certified & $\begin{array}{c}\text { Organic food } \\
\text { ISO9001 }\end{array}$ & HACCP & $\begin{array}{c}\text { Organic food } \\
\text { milk }\end{array}$ & HACCP \\
& Price & ISO9001 & \\
[Yuan/L] & $\mathbf{1 5}$ & $\mathbf{2 8}$ & $\mathbf{2 8}$ & $\mathbf{2 2}$ \\
Number & $\mathbf{5 0}$ & $\mathbf{1 6}$ & $\mathbf{3 6}$ & $\mathbf{3 4}$ \\
\hline
\end{tabular}

Table 3 Organic food, ISO9001 certification and HACCP certification, consumer choice under different prices

\begin{tabular}{|c|c|c|c|c|c|c|c|}
\hline \multicolumn{2}{|c|}{$\begin{array}{c}\text { Item } \\
\text { Same condition }\end{array}$} & \multicolumn{2}{|c|}{$\begin{array}{c}\text { A } \\
\text { Same size and } \\
\text { brand of milk }\end{array}$} & \multicolumn{2}{|c|}{$\begin{array}{c}\text { B } \\
\begin{array}{c}\text { Same size and brand } \\
\text { of milk }\end{array}\end{array}$} & \multicolumn{2}{|c|}{$\begin{array}{c}\text { C } \\
\begin{array}{c}\text { Same size and brand } \\
\text { of milk }\end{array}\end{array}$} \\
\hline $\begin{array}{l}\text { Cond- } \\
\text { ition }\end{array}$ & Certified & $\begin{array}{c}\text { Organic } \\
\text { food }\end{array}$ & $\begin{array}{l}\text { HACCP } \\
\text { ISO9001 }\end{array}$ & $\begin{array}{c}\text { Organic } \\
\text { food }\end{array}$ & $\begin{array}{l}\text { HACCP } \\
\text { ISO9001 }\end{array}$ & $\begin{array}{c}\text { Organic } \\
\text { food }\end{array}$ & $\begin{array}{l}\text { HACCP } \\
\text { ISO9001 }\end{array}$ \\
\hline & $\begin{array}{c}\text { Price } \\
{[\text { Yuan/L] }}\end{array}$ & 15 & 28 & 28 & 22 & 8 & 22 \\
\hline & imber & 36 & 33 & 15 & 53 & 13 & 44 \\
\hline
\end{tabular}

Item $\mathrm{B}$ of table 3 , with item $\mathrm{A}$ of table 2 , under the effect of low price and most quantity attestation, the consumer chooses the quantity of this milk to be much more than another kind of milk, and the price difference is bigger, the performance is more obvious. From item $\mathrm{C}$ of table 3,or item B of table 2, price is not the most important factor for consumers in comparison with the number of certified quantities, but it has an impact on consumer choice, narrowing the gap caused by the number of food quality and safety certification (see table 2, table 3 ).

In the case of low price difference, consumers pay more attention to the price factor than to the certification factors, the number of certification still dominate. However, when the price difference is more (more than 10 yuan), such as Table 3 Item A, the impact of price factors will be greater than the impact of certification, price factors not only shortened by the certification caused by the gap.

In summary: Consumers pay more attention to the quantity of food safety certification than the 
price, but the difference between the two commodity prices will shorten the quality and safety certification caused by the gap, or even the go-ahead.

\section{Summary}

First, consumers must establish a sense of responsibility, take the initiative to understand the safety of quality certification knowledge, develop good consumption habits, reduce information blind spots, reasonable reduce their subjective risk awareness, rational consumption. Consumers can strengthen the relationship between consumers and enterprises through joint or with the docking of production enterprises, further breaking the information asymmetry between them, rebuilding trust and eliminating subjective risk in cooperative communication.

Second, enterprises should standardize production standards, actively participate in the certification of Governments and international organizations, effectively pass the certification information, so that consumers can buy at ease; On the other hand, through the effective propaganda means, to the consumer to pass the reliable quality information of food, in order to reduce the consumer's subjective.

Third, the Government should timely quality certification and other food quality information published in the public, conductive correct certification information, guide consumers, and actively participate in food safety common governance system. Moreover, the consumer participation in the supervision of the conduct of incentives, will further improve the level of food safety supervision. In the face of consumer questioning, the Government should be given a correct and timely response, scientific treatment of public opinion, to guide the atmosphere of safety.

\section{References}

[1] Mitchell, V-W. Consumer perceived risk: conceptualisations and models. European Journal of Marketing, 1999, 33(1/2), 163-195

[2] Yeung, P.M., \& Morris, J. Food safety risk: Consumer perception and purchasae behavior. British Food Journal, 2001b, 103(3), 170-186

[3] KNOX, B. Consumer Perception and Understanding of Risk from Food[J]. British Medical Bulletin,2000,(1):97-109

[4] Mahon, D., \& Cowan, C. Irish consumers' perception of food safety risk in minced beef. British Food Journal, 2004, 106(4), 301-312

[5] Huang, C. L. Simultaneous-equation model for estimating consumer risk perceptions, attitudes, and willingness-to-pay for residue-free produce. The Journal of Consumer Affairs, 1993, 27(2), 377-396

[6] Hornibrook,S. A., McCarthy, M.,\& Fearne, A. Consumers' perception of risk: the case of beef purchases in Irish Supermarkets. International Journal of Retail \& Distribution Management, 2005, 33(10), 701-715

[7] Bai J F. The acceptance and purchasing intention of GM food for the Chinese city consumers. [D].Chinese Academy of Agricultural Sciences,2003(in Chinese)

[8] Zhou J H. The analysis of consumers'attitudes vognitions and purchasings for the vegetable safety[J]. Chinese Rural Economy,2004(11):44-52.(in Chinese)

[9] Hou B, Yang J, Wu L H. The literature review on the influences of the residues of pesticides to agricultural products and farmers' knowledge and factors about the residues of pesticides [J].Anhui agricultural Sciences, 2010,38(04):2098-2101+2129. (in Chinese)

[10]Zhang C P, Bai J F, Jiang J.The influences of certificates to willingness to pay :the traceability of milk[J].Chinese Rural Economy,2014(08):76-85. (in Chinese) 